\title{
The Asean Way and Haze Mitigation Efforts
}

\author{
Helena Muhamad Varkkey
}

Abstract

Transboundary haze pollution is an almost annual occurrence in Southeast Asia. Haze originates from peat and forest fires mostly in Indonesia, with Malaysia and Singapore suffering the worst of its effects. Most of these fires are manmade, and linked to land clearing activities of local and foreign commercial oil palm plantations. The regional nature of haze has concentrated mitigation activities at the ASEAN level. However these initiatives continually fail to effectively mitigate haze. This article argues that haze mitigation has been problematic due to the ASEAN style of regional engagement, which prioritizes the maintenance of national sovereignty. States are compelled to act in their national interests, as opposed to the collective regional interests. The economic importance of the oil palm sector to the states involved, coupled with traditionally close relationships between key economic actors and political elites, meant that the maintenance of the status quo, where major plantation companies could continue to clear land using the cost-effective method of burning, was of crucial national interest. Therefore, the ASEAN style of regional engagement has enabled member states to shape ASEAN initiatives to preserve the interests of these political and economic elite, while the public continue to suffer the haze.

Keywords: Transboundary, haze pollution, environmental issues, ASEAN-way mitigation efforts.

\section{Introduction}

Transboundary haze is the Southeast Asian region's first and most publicly-identifiable regional environmental crisis (Elliott, 2003). This haze has been an annual recurring problem since the 1980s. Haze is smoke that originates from peat and forest fires, mostly in Indonesia, and becomes transboundary when it travels across national boundaries. The haze affects the health of some 75 million people and the economies of up to six Southeast Asian nations, with Indonesia, Malaysia, and Singapore being the most severely affected (Mayer, 2006). Research has shown that most of these fires are manmade, and can be traced back to illegal land clearing activities of commercial local and foreign (mostly Malaysian and Singaporean) oil palm plantations (Caroko, Komarudin, Obidzinski, \& Gunarso, 2011; Casson, 2002; Colfer, 2002; Fairhurst \& McLaughlin, 2009; K. T. Tan, Lee, Mohamed, \& Bhatia, 2009). Using fire is the most cost-effective way to clear land in preparation for commercial planting (Interviewee I49, 2011). ${ }^{1}$

Southeast Asian states have largely elected to address the issue of transboundary haze through collaboration at the regional level through the Association of Southeast Asian nations (ASEAN), with limited success. This paper argues that the regionalism of haze mitigation through ASEAN initiatives have failed to curb haze because the ASEAN model 
of regionalism which emphasizes national sovereignty and self-determination (Interviewee A7, 2010; Narine, 1998a; Smith, 2004; Zainal Abidin [M38], 2010), has allowed member states to shape collective mitigation initiatives at the ASEAN level in accordance with the interests of political and economic elites. Nesadurai has argued that "the ASEAN Way is often only strictly adhered to and enforced by states in areas where crucial economic interests are affected' (Nesadurai, 2008). Maintaining current practises in the region's oil palm plantation sector is indeed an area of crucial economic interest for Indonesia, Malaysia and Singapore, firstly due to its substantial contribution to GDP, and secondly due to the traditionally close relationships between key economic actors and political elites (Nesadurai, 2003). This paper therefore argues that the states involved have chosen to adhere to the ASEAN Way when dealing with the haze to preserve crucial economic interests in the oil palm plantation sector. At the ASEAN level, this has resulted in initiatives that protect elite corporate interests, preserve state sovereignty, and deflect responsibility on the haze issue (Tan [S7], 2010; Yahaya [M13], 2010).

This article is divided into two sections. The first section introduces the concept of political regionalism. It notes that, while regionalism has been viewed in the literature as an important strategy for resolving common environmental problems, the ASEAN model of regionalism, with its selective use of the ASEAN Way principles by member states, has not been conducive to this. The second section reviews the ASEAN haze initiatives. Using data obtained from fieldwork consisting of archival research and semi-structured interviews conducted in Indonesia, Malaysia and Singapore among government officials, Non-Governmental Organization (NGO) representatives, journalists, and academicians, this paper argues that states chose to adhere to the ASEAN Way principles while shaping these initiatives. As a result, these initiatives have largely been ineffective in curbing haze, but effective in protecting the interests of the business elites. As a whole, this article argues that ASEAN is not the appropriate forum to effectively carry out haze mitigation, because the ASEAN style of regionalism allows for states to act in the interests of their political and economic elites, as compared to the collective interests.

\section{The Regionalism of Environmental Issues}

Indonesia is currently the world's biggest producer of palm oil (Bernama, 2010; Jarvis, et al., 2010; Mccarthy, 2010; Reuters, 2011; World Growth, 2011), contributing to about $51 \%$ of world production ( $\mathrm{Di}, 2011)$. In terms of revenue, palm oil contributes around $5 \%$ of Indonesia's GDP annually (iStockAnalyst, 2009). Alongside powerful Indonesian companies like Bakrie Sumatra Plantations, Duta Palma, Astra Agro, Makin Group, and Musim Mas (Van Gelder, 2004), many well-connected Malaysian and Singaporean companies have also established operations in Indonesia. For example, Sime Darby and Tabung Haji Plantations are prominent Malaysian GLCs, while Genting Plantations, Kuala Lumpur Kepong and IOI Plantations are owned by powerful and well-connected ChineseMalaysian tycoons (Gomez, 2009). Currently, Malaysian and Singaporean companies hold more than two-thirds of Indonesia's total plantation area (WALHI, Sawit Watch, \& 
CELCOR, 2009). Malaysian investments have an investment value of US\$ 702.4 million and Singaporean investments in the sector amount to US\$ 11.2 million (Sawit Watch, 2008). In this way, oil palm has become an increasingly important economic sector for Indonesia, Malaysia and Singapore (Pichler, 2011). Due to the traditionally close relationship many of these companies enjoy with their respective countries' political elite, these companies have largely been able to act with impunity in their operations to maximise profit, but with the side effect of transboundary haze.

However, as awareness of the source and dangers of smoke haze spread, Southeast Asian governments increasingly came under pressure from the public and civil society at the national, regional, and international level to address the haze issue(Ho, 1997; Interviewee I25, 2010; Interviewee S4 \& Interviewee S5, 2010; Interviewee S18, 2010; Lim [S13], 2010; New Straits Times, 1997). There is an assumption in the literature that as the demand for regional cooperation increases (in this case, the demand for haze mitigation by civil society) because of deepening economic regionalization, it will be matched by a 'supply' of appropriate regional institutions (Jayasuria, 2004). Hence, in 1997, the Myanmar Foreign Minister who chaired Environmental Affairs at ASEAN at the time suggested that the haze should be addressed at the ASEAN level separately from other environmental issues (Interviewee A2, 2010) due to its transboundary nature, its extreme impact to society, and its close relation to natural resource management (Interviewee A7, 2010; Mat Akhir [A1], 2010). ASEAN member countries unanimously supported this as an opportunity to address civil society's concerns. This marked the start of the 'regionalism' of haze mitigation at the ASEAN level (Interviewee A2, 2010).

'Political regionalism' refers to top-down, state-led projects of cooperation that emerge as a result of intergovernmental dialogues and treaties (Breslin \& Higgott, 2003). This type of political regionalism focuses on regional inter-state cooperation, involving the negotiation and construction of inter-state agreements or regimes. Regionalism may involve the creation of formal institutions, but it can often be based on a much looser structure, involving patterns of regular meetings with some rules attached, together with mechanisms for preparation and follow up. Such cooperative arrangements can serve a wide variety of purposes: to secure welfare gains; to promote common values; or to solve common problems, especially problems arising from increased levels of regional interdependence (Hurrell, 1995). Political regionalism therefore 'involves a set of social functions that is concerned with making collective choices among people delineated by geographical proximity and other shared notions of sameness' (Boas, 2000).

The regionalism of environmental issues has been viewed in the literature as an important strategy for resolving common environmental problems. Regionalism scholars argue that action at the regional level should be able to help aggregate individual national policy positions around a joint position, and thus facilitate both the establishment and the implementation of multilateral agreements(Koh \& Robinson, 2002). For example, scholars such as Koh and Robinson (2002) and Hurrell (1995) have argued that regional systems 
of environmental management can be an important complement to national governance in solving common regional environmental problems. As Campbell (2005) argues:

\begin{abstract}
"Environmental regionalism is often viewed as a more feasible, effective, and democratic approach for addressing environmental problems that transcend national boundaries ... Primarily because a small number of countries are involved, regionalism is seen as more likely to facilitate participation and represent the interests of all the parties ... Regional commonalities such as geography, culture, values, and economic and political systems, combined with a smaller number of countries needed for consensus, will make agreement easier to reach”.
\end{abstract}

However, this paper argues that the model of regionalism is an important determinant on whether the regionalism process is effective in solving regional problems or not. For example, the European Union's (EU) model of regionalism is characterized by supranational institutions and the pooling of sovereignty. In ASEAN, the maintenance of national sovereignty remains the focus of regionalism. Therefore, the ASEAN model of regionalism differs from the EU, owing to different emphases on sovereignty (Kim, 2011; Murray, 2010). This difference means that some forms of transnational coordination and cooperation are simply more feasible in Europe than they are in Southeast Asia (Beeson, 2007). The following paragraphs discuss the ASEAN style of regionalism, noting that this model has generally not been conducive in collectively addressing Southeast Asian environmental issues.

ASEAN was founded to help accelerate economic growth, social progress, and cultural development in the region (ASEAN Secretariat, 2009). These goals are expressed in various ASEAN treaties including its founding document, the 1967 Bangkok Declaration (Katanyuu, 2006). These documents also prescribe approaches to regional engagement, known collectively as the ASEAN Way, a set of behavioural and procedural norms. These include the search for consensus; the sanctity of sovereign rights and non-interference; the principles of sensitivity and politeness; non-confrontational approaches to negotiations; behind-the-scenes discussions; an emphasis on informal and non-legalistic procedures; and flexibility (Kivimaki, 2001).

A common explanation for the persistence of the haze is the limitations posed by the ASEAN Way of regional governance. Scholars like Tan (2005), Tay (2002), Yahaya (2000), Nguitragool (2011), and Chang and Rajan (2001) have argued that while regional environmental governance can be instrumental in finding solutions to collective action problems, this model of ASEAN cooperation does not work when dealing with environmental challenges such as fires and haze. Scholars have argued that because the ASEAN Way is too deeply engrained in the process of regional governance in ASEAN, member states cannot imagine ASEAN functioning any other way (Kamaruddin [M26], 2010; Lew [M6] \& Interviewee M7, 2010; Nagulendran [M34] \& Interviewee M35, 2010; Syarif [I2], 2010); 
Severino (2006) has described the ASEAN Way as a 'doctrine'; something ideological and therefore, to be adhered to at all costs. Therefore, Aggarwal and Chow (2010) insist that ASEAN states 'undoubtedly desire the elimination of the haze problem', but were unable to balance this desire with their stronger desire to comply with broader ASEAN Way norms of non-interference and decision making by consensus.

These scholars argue that the persistence of the haze can be explained by the fact that the ASEAN organization is too tightly bound to these norms as guidance devices for decisionmaking (Kratochwil, 1984, 1989; Narine, 1998b). They argue that due to the necessarily strict adherence to the ASEAN Way, environmental problems in ASEAN like the haze are approached through the non-interference principle. This impedes collective problemsolving methods when dealing with natural resource issues, as other states are not allowed to pressure members into acting in accordance with collective interest. Because of this, it is argued that ASEAN states struggle to draw a line between respecting their neighbouring government's right to self-determination and cooperatively mediating the haze situation which ultimately affects the entire region (Tan, 2005). Therefore, ASEAN has emphasized policy pronouncements and rhetoric over actual implementation of effective haze mitigation efforts (Chang \& Rajan, 2001), largely rendering them ineffective.

This article finds these arguments flawed. States do not blindly follow the ASEAN Way principles due to some deeply ingrained 'habit'. On the contrary, this article argues that states choose to adhere to the ASEAN Way if it is in their interests to do so. This is the crux of the ASEAN model of regionalism. While the European model of regionalism is characterised by the pooling of sovereignty, the ASEAN model is characterised by its maintenance of national sovereignty (Kim, 2011; Murray, 2010). This difference in emphases of sovereignty explains why environmental regionalism in Europe has been successful while environmental regionalism in Southeast Asia has not. While the main drivers of the EU are its supranational institutions, the main drivers of the ASEAN organization are member states (Interviewee A7, 2010; Narine, 1998a; Smith, 2004; Zainal Abidin [M38], 2010). Unlike the European Commission, the ASEAN Secretariat has been deliberately denied the resources and mandate necessary to carry out such a responsibility (Kim, 2011), and continues to be subordinate to national secretariats (Beeson, 2007; Solingen, 2005). This ASEAN model of regionalism therefore enables member states to control the scope, depth and speed of regionalism in ASEAN, which best suits their national interests (Kim, 2011). Therefore, while decisionmaking in the EU is geared towards the collective interest, decision-making in ASEAN is shaped according to the interests of its member states (Interviewee A7, 2010). Hence, states are free to decide whether or not to adhere to ASEAN Way norms, depending on whether it is in their best interests. Instead of being a limiting effect on state behavior, the ASEAN Way can be better explained as tools for political action that states can selectively use in line with their interests (Khoo, 2004).

Subscribing to the ASEAN Way when necessary shields national governments from having to commit to addressing joint tasks that governments either find too demanding 
administratively, politically difficult (if these went against dominant national interests), or not sufficiently important given a set of national priorities. In keeping with non-interference norms, the parties can stress the primacy of national laws, policy-making and implementation (Elliott, 2003). In keeping with the procedural voluntarism of the ASEAN Way, parties can avoid legally binding agreements. This clause, along with sovereignty concerns has also resulted in a lack of central institutions in ASEAN to uphold compliance or any credible mechanisms for settling disputes in an objective and binding manner (Severino, Hew, Suryadinata, Hsu, \& Moeller, 2005). This complicates the application of multilateral pressure and collective problem-solving methods (Tan, 2005). The non-interference clause also enables governments to exclude any issue deemed to be politically sensitive from ever being discussed at the regional level (Nesadurai, 2008). As a result, these principles provide members with considerable autonomy to determine the extent to which they would implement regional environmental agendas, even those that they have agreed to initially (Nesadurai, 2008). Indeed, as an institution centered around the promotion of economic cooperation and prosperity among its members (Smith, 2004), environmental objectives are therefore often overlooked in the pursuance of these economic goals.

Furthermore, as mentioned above, the relationship between key economic actors and national political elites in Southeast Asia are traditionally very close (Nesadurai, 2003). These relationships prevalent within the region's forestry and agricultural industry (Aggarwal \& Chow, 2010) has meant that many political parties in power have direct links to natural resources (Resosudarmo [I26], 2010). This situation encouraged elites to favour arrangements that ensure domestic and regional political economic stability and market access to these natural resources (Solingen, 1999), while providing a lack of incentives for effective regional environmental conservation. This paper therefore argues that the protection of these elite interests was more important than responding to environmental issues through ASEAN (Cotton, 1999).

As a result, ASEAN developed into an elite-centered framework of regionalism (Ferguson, 2004), where (elite) economic growth takes precedence over environmental protection (Nesadurai, 2008). States were unwilling to antagonize domestic interests by applying prohibitive national or regional-level environmental law, particularly when such natural resource interests are tightly bound to a leader's political power base (Aggarwal \& Chow, 2010; Boas, 2000). Member states sought to protect the interests of the political and economic elites by maintaining their 'power of veto' (by denying such a mandate to its Secretariat) over effective policy innovation at the ASEAN level (Cotton, 1999). Therefore, member states were free to pick and choose instances where they would strictly follow the ASEAN Way, or ignore it, as long as it was in the interests of the member states' political and economic elites.

Hence, with national priorities skewed to elite interests connected with national resources, ASEAN initiatives have thus far had a strong preference in the observation of the ASEAN Way where protection of the regional environment is concerned (Abdullah, 2002). The 
application of the ASEAN Way has enabled members to retain a great degree of domestic policy autonomy (Nesadurai, 2008) over environmental matters. Hence, ASEAN operates not from any set of strict legal procedure like the EU but instead, by creating sequential issue-by-issue ad-hoc coalitions (Pempel, 2005). Declarations and agreements adopted at the ASEAN level usually articulate mere 'principles' for regional environmental cooperation but rarely include guidelines for national environmental practice which could be construed as 'intervention' (Elliott, 2003). Therefore, ASEAN environmental initiatives have relied on voluntary cooperation, non-binding agreements, and a weak institutional infrastructure (Campbell, 2005) emphasizing aspirational policy pronouncements and rhetoric over actual implementation (Chang \& Rajan, 2001).

This rhetoric has had no observable impacts on the intergovernmental policy practices of the ASEAN members and have failed to transform their trade and investment patterns (Kim, 2011). Greater priority has thus been attached to economic growth than to health and environmental protection in ASEAN (Campbell, 2005). While member states acknowledge that they had environmental problems in common, their material interests in addressing them arose from the importance of domestic economic progress and development. Therefore, it was more important for these states to maintain the availability of, and access to natural resources (Elliott, 2003) like timber and forest products to be used in the pursuit of development. In this way, adherence to the ASEAN Way provides an avenue for member states to pursue their national interests with minimal resistance, while ensuring that the regional atmosphere is healthy and supportive. As a result, effective cooperative regional arrangements over environmental issues at the ASEAN level have been problematic (Elliott, 2000, 2001, 2003; Karim, 2008). These problems of course extend to haze mitigation activities at the ASEAN level, which the following section discusses.

This paper argues that ASEAN states were pressured by civil society to act upon the haze, but at the same time also faced economic pressures from the region's oil palm plantation sector. Therefore, states had to address both concerns from civil society and the economic elite by engaging at the ASEAN level over haze, but in a way that would maintain the status quo of privileging economic actors in the oil palm plantation sector that are close allies of the political elite. To do this, ASEAN states chose to largely adhere to the ASEAN Way in regards to haze cooperation. Therefore, ASEAN initiatives on haze have resulted in outcomes that protect national economic interests, preserve state sovereignty, and deflect responsibility on the haze issue (Tan [S7], 2010; Yahaya [M13], 2010), instead of actually reducing or eradicating haze.

Through a chronological examination of ASEAN haze initiatives, the following discussion argues that the observance of the ASEAN Way principles of sovereignty, non-interference and economic development above all have resulted in outcomes that were largely ineffective in curbing haze, but effective in protecting the interests of the business elites and further encouraging the unscrupulous practises of the region's oil palm plantation industry. In short, this section argues that these cooperative agreements that were produced have been 
deliberately designed by member states to protect national economic interests and preserve state sovereignty, while deflecting responsibility on the haze issue (Tan [S7], 2010; Yahaya [M13], 2010).

\section{ASEAN-Level Haze Mitigation Initiatives}

ASEAN as an organization began to acknowledge haze as a regional concern in 1985 , with the adoption of the Agreement on the Conservation of Nature and Natural Resources, which made specific reference to air pollution and 'transfrontier environmental effects' (ASEAN Secretariat, 1995). This was followed over the years by other agreements with references to transboundary pollution, like the 1990 Kuala Lumpur Accord on Environment and Development and the 1992 Singapore Resolution on Environment and Development (ASEAN Secretariat, 1995). Indeed, the 1992 Singapore Resolution identified such transboundary pollution as a major environmental concern, and the same year, ASEAN environmental ministers agreed to harmonize policy directions and establish operational and technical cooperation, with special reference to haze (Tay, 2008). Following this, the first Workshop on Transboundary Pollution and Haze in ASEAN Countries was held in Balikpapan, Indonesia in September 1992, specifically addressing the haze as an individual problem in the region (ASEAN Secretariat, 1995). The first informal ASEAN Ministerial Meeting on the Environment in Kuching, Sarawak in 1994 marked the beginnings of a more visible effort by the ASEAN member countries to address the continuous problem of the haze. Here the ministers agreed to enhance cooperation to manage natural resources and control transboundary pollution within ASEAN, to develop an early warning and response system, and to improve the capacity of member countries in these areas (Yahaya, 2000).

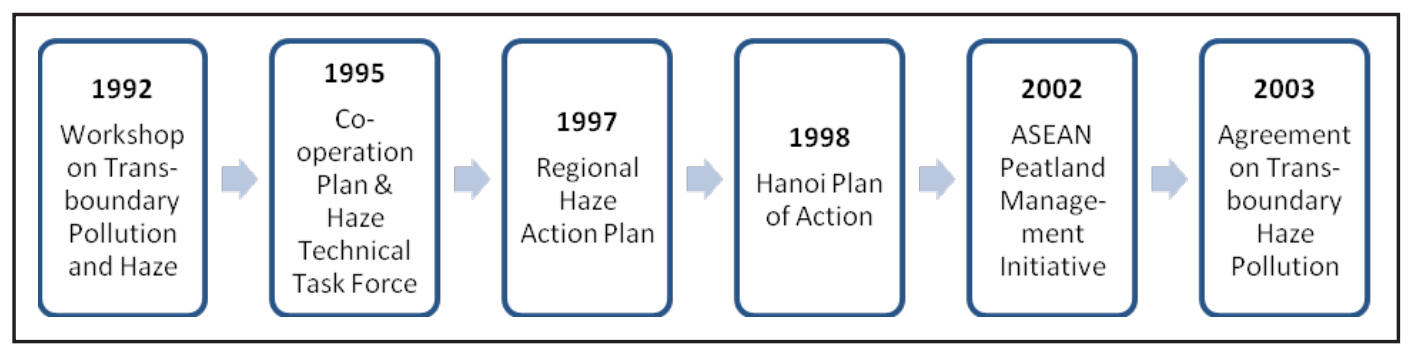

Figure 1. ASEAN initiatives relating directly to haze.

In 1995, member states agreed to adopt an ASEAN Cooperation Plan on Transboundary Pollution (Severino, 2006). The plan set out the broad policies and strategies to deal with atmospheric and other forms of transboundary pollution (Severino, 2006) including a number of concrete measures to prevent and respond to the fires and haze, such as the promotion of zero-burning practices, the deployment of ground forces to prevent and detect forest fires, and the establishment of National Focal Points to strengthen regional coordination (Nguitragool, 2011). As a follow up to this plan, the ASEAN Senior Officials on the Environment Meeting established a Haze Technical Task Force (HTTF) with the objective of putting into operation the measures included in the Cooperation Plan (Severino, 
2006). It outlined the efforts to be made at both national and regional levels (Tay, 1998). The Ministers also agreed to develop a common air-quality index and a regional fire-danger rating system (Tay, 2002). Countries also agreed to share knowledge and technology on the prevention and mitigation of forest fires, and to establish a mechanism for cooperation in combating forest fires (Tay, 1998).

At the suggestion of the ASEAN Chair of Environmental Affairs (Interviewee A2, 2010) in 1997, the ASEAN Ministerial Meeting on Haze was established. This marked the beginning of the specific regionalism of haze mitigation at the ASEAN level, with the haze being given a special status of importance in the organization, separate from other transboundary environmental issues. The Meeting formulated the Regional Haze Action Plan (RHAP) under the HTTF to provide further commitments and detail to the Cooperation Plan (Evans, 2001). In the spirit of the ASEAN Way, the RHAP was designed to overcome the haze problem with concerns of culture, economy and individual governments in mind (Abdullah [M43], 2011). It was a soft-law, non-binding instrument which stood on three pillars: the spirit of voluntarism, the no-fault finding rule, and the offer of assistance based on expertise and capability (Florano, 2004). Under the RHAP, member parties were obliged to develop their own plans, guidelines, and other measures to prevent and monitor fires that could cause transboundary haze pollution.

The plan was divided into three parts. The first required member states to draw up national plans based on the regional plan. The second sought to strengthen the monitoring and anticipation of forest fires and increased pollution levels through the ASMC in Singapore. The third focused upon the enhancement of fire fighting capability (Jones, 2006). It also established an ASEAN Policy on Zero Burning. These guidelines for zero burning however were not meant to be prescriptive and controlled burning continued to be allowed for 'specific situations'. Other aspects emphasized in the RHAP included the identification and mobilization of resources, the exchange of information, and the development of markets for biomass and agricultural wastes, which are otherwise disposed of by burning (Nguitragool, 2011). Furthermore, it solidified the breakdown in haze mitigation roles at the ASEAN level according to the country's expertise (Yahaya, 2000): Malaysia for prevention, Singapore for monitoring and Indonesia for firefighting (Woon, 2002).

In 1998, the ASEAN Summit in Vietnam issued the Hanoi Plan of Action that called for full implementation of the RHAP by 2001 (Yahaya, 2000). It established a procedure by which fire fighting resources could be pooled for regional fire-fighting operations (S. Tay, 2008). Specifically, it established two Sub-Regional Fire-Fighting Arrangements (SRFA) for Borneo and the Sumatra/Riau provinces in Indonesia under the RHAP to facilitate the movement of resources from one member country to the other on order to mitigate the haze problem (Yahaya, 2000). To complement the SRFA, a SRFA Legal Group was established in 2000 to examine the legal and enforcement issues in the region related to curbing forest fires (Jones, 2006). 
In 2001, an Agreement on Transboundary haze Pollution (ATHP) was proposed to provide legally binding support for the RHAP (Florano, 2003). The ATHP was signed by all ten ASEAN member countries in 2002, in Kuala Lumpur. With the entry into force of the ATHP in 2003, specialised Technical Working Groups were tasked to develop the Comprehensive ASEAN Plan of Action on Transboundary Haze Pollution (ASEAN Secretariat, 2007). The resulting Plan of Action included a cooperation mechanism for members to help Indonesia prevent haze by controlling fires, establishing early warning systems, exchanging information and technology, and providing mutual assistance (Khalik, 2006). Furthermore, a Panel of Experts (POE) was established to provide rapid independent assessment and recommendations to governments for the mobilization of resources. Article 5 of the ATHP also called for the establishment of an ASEAN Coordinating Centre for Haze in Indonesia, and a supporting ASEAN Haze Fund (ASEAN Secretariat, 2002; Hudiono, 2003; Kurniawan, 2002).

An ASEAN Peatland Management Initiative (APMI) was proposed at the $9^{\text {th }}$ ASEAN Ministerial Meeting on Haze in 2002. This initiative was to complement the SRFA initiatives with a special focus on addressing issues of fire prevention and control in the region's peatlands. The initiative was established in collaboration with the Global Environment Center, an NGO focusing on peatland conservation in the region. The goals of the APMI are to promote sustainable management of peatlands through collective efforts and enhanced cooperation among ASEAN member countries towards achieving local community support and sustaining traditional livelihood options (Anshari [I42], 2011), to promote regional benefits through reduced risk of fire and associated haze, and to contribute globally in minimizing impacts of climate change as a result of carbon release from peatlands(ASEAN Secretariat, 2003).

On top of these plans and agreements, other ASEAN initiatives on the haze include detailed operational procedures for monitoring, assessment and joint emergency response; the formation of a regional network made up of national focal points; an inventory of fire-fighting resources and training mechanisms; simulation exercises for joint emergency response between countries; and demonstration sites for the benefit of farmers, smallholders and shifting cultivators (ASEAN Secretariat, 2004). As mentioned above, the political impetus for these initiatives were that states came increasingly under pressure from the public and civil society at the national, regional and international level to address the haze issue as awareness of the source and dangers of smoke haze spread (Ho, 1997; Interviewee I25, 2010; Interviewee S4 \& Interviewee S5, 2010; Interviewee S18, 2010; Lim [S13], 2010; New Straits Times, 1997). However, this plethora of plans and projects over the decades failed to break the persistent cycle of haze in the region.

Efforts to address the Southeast Asian haze have overwhelmingly originated from the ASEAN level (ASEAN Secretariat, 1995; Letchumanan [A6], 2010; Severino, 2006; Yahaya, 2000). Indeed, regional collaboration over the haze became very high profile and was pegged as 'the earliest example of ASEAN cooperation over transboundary issues' (Elliott, 2003; 
Interviewee A2, 2010). Several scholars and agencies have praised ASEAN haze mitigation efforts. For example, the United Nations Environment Programme (UNEP) hailed the ASEAN Way of haze collaboration (enshrining sovereignty and non-interference) as a pioneering achievement that could become a global model for the tackling of transboundary issues (Severino, 2006). It was envisioned that there would be an increasing emphasis of cooperative measures (carrots, like those prescribed in the ASEAN Way) instead of sanctions and strict state responsibility (sticks) as guidance devices for actions among other regions and in other international environmental regimes in the future (Tay, 2002). Scholars also argued that soft law agreements as is prevalent in ASEAN haze initiatives saved time, as ASEAN was able to immediately get the cooperation of Indonesia, which would have been unlikely under the threat of sanctions (Cotton, 1999; Florano, 2004). Solingen (2005) noted that such informal agreements could better facilitate cooperation because they make fewer informational demands on the parties, can be negotiated quickly, and can be rapidly modified as conditions change. These scholars further argued that these tactics enabled ASEAN to test and adjust their strategies without them being set in stone (Florano, 2004), and has led to enhanced contact between officials and experts across ASEAN (Cotton, 1999). Other scholars say it has been useful in attracting funding (Florano, 2004; Mayer, 2006) and technical assistance, as once a regional machinery is established based on local volunteerism, contributions from the international community would be expected to pour in (Florano, 2004). In this sense, ASEAN haze collaboration can be seen as providing symbolic diplomatic rather than legal pressure on culprits (Mayer, 2006), which have been viewed positively by the scholars and agencies mentioned here.

However, despite these positive reviews, the regionalism of haze mitigation has failed to bring about meaningful results, and the haze persists as a regional pollution problem year after year (Campbell, 2005). While scholars like Koh and Robinson (2002) have argued that such regionalism should be able to help aggregate individual national policy positions around a joint position and facilitate both the establishment and the implementation of multilateral agreements, other scholars have argued that high levels of political regionalism in Southeast Asia are no guarantee of the effectiveness of solving such common problems (Hurrell, 1995). With member states being the main drivers of the organization, these states were able to shape the (albeit high levels of) regionalism of haze mitigation to privilege economic actors in the region's oil palm plantation sector that are close allies of the political elite (Nesadurai, 2003). The ASEAN model of regionalism often results in a reassertion and extension of state authority as states seek out a greater degree of practical influence over the policies of other states and over the management of common problems (Hurrell, 1995). Accordingly, this paper will show that states have elected to adhere to ASEAN Way principles as a way to reassert their authority and their right to self-determination over the haze issue, resulting in the continuing haze. More importantly, this enables them to continue to protect their crucial economic interests in the regional oil palm plantation sector (Campbell, 2005).Therefore, the regionalism strategy of addressing haze through ASEAN unsurprisingly fails to deliver environmentally positive results. 


\section{ASEAN Way Regionalism}

In the regionalism literature, binding agreements, an institutionalized system, and the sectoral integration of policies are often singled out as some of the most important factors that render the regionalism process a success (Murray, 2010; Shelton, 2003). A close observance of these ASEAN initiatives on haze however reveals that these ASEAN Waycompliant initiatives rarely contained these important factors for success. For example, the 1998 Cooperation Plan on Transboundary Pollution and its complementary HTTF was found to be much less formal or binding than comparable documents in other regions such as Europe for curbing transboundary harm (Tay, 2008). The plan was largely a listing of general actions that governments ought to take to prevent and mitigate forest fires (Severino, 2006). The absence of specific operational directives rendered the plan ineffective, and member countries were again thrown into crisis-management mode with the advent of the most serious haze of the region in 1997 to 1998 (Tay, 2008). Likewise, the 1998 RHAP continued to focus on national plans and capabilities instead of regional initiatives (Tay, 1998). Like the Cooperation Plan, the RHAP exemplified a 'soft law' approach and was also not a legally binding agreement (Tay, 2008). It was left to the governments concerned to decide what was to be included in their national plans, with the freedom to bypass or equivocate on matters raised in the RHAP (Jones, 2006). There were no mechanisms under the plan for any member country to ensure that the other member countries fulfilled their obligations (Parliament of Singapore, 1998).

Even the legally binding ATHP displayed many shortcomings. Regional engagement focusing on the maintenance of national sovereignty within ASEAN (Kim, 2011; Murray, 2010) meant that states were compelled to ensure that the ATHP, even when legally binding, still observed their national interests, as opposed to the collective regional interest. Member states did this by insisting on close adherence to the spirit of the ASEAN Way. This ensured that the ATHP, while legally binding, was a highly watered down document where the costs of cooperation for concerned parties are greatly lowered (Nguitragool, 2011). This resulted in a treaty that, although technically legally binding, was "vague and lacking in various hard-law instruments such as strong dispute-resolution and enforcement mechanisms. Important provisions, including those for developing preventive measures, and a national emergency response, are left to member parties to interpret and apply' (Nguitragool, 2011). Furthermore, as Article 27 of the Agreement states, 'any dispute between Parties as to the interpretation or application of, or compliance with, this Agreement or any protocol thereto, shall be settled amicably by consultation or negotiation' (ASEAN Secretariat, 2002). Hence, the ATHP did not significantly differ from the RHAP in either substance or in demands for member parties to make policy changes (Nguitragool, 2011).

As a result, most of the ASEAN initiatives on haze since were useful in generating a massive amount of information on the haze (Severino, 1999) but not much in terms of effective implementation of haze mitigation activities. The focus on national plans and the lack of legally binding documents ensured that states were largely free to pick and choose regional 
initiatives that best suited their narrow economic national interests. For example, the RHAP established the role of the ASMC as the region's mapping, imaging and forecasting provider for fires and haze. However, Malaysia used sovereignty arguments to strongly oppose the use of satellite data for haze monitoring purposes at the regional level during the early years of the haze (Campbell, 2005). Also, meteorological officials from Indonesia's Lembaga Penerbangan dan Antariksa Nasional (Indonesian National Institute of Aeronautics and Space) that were interviewed said that Indonesian ministries also used similar arguments to explain their lack of acceptance of ASMC data. Indonesia preferred to use their own, less advanced meteorological data for fire mapping and haze monitoring (Haryanto [I16], 2010; Roswiniarti [I13], 2010). In respect for Indonesia's sovereignty, ASEAN could not insist on Indonesia's use of ASMC data. This choice of inferior fire mapping by Malaysia and Indonesia of course enables many local and foreign plantation companies in Indonesia to avoid scrutiny of fire activities on their land. Furthermore, even though the SRFA was meant to quickly facilitate the movement of fire-fighting resources from one member country to the other in the event of fires (Yahaya, 2000), Indonesia was known to turn down or unnecessarily delay entry of regional fire-fighting teams even though all requirements for the activation of SRFA assistance was fulfilled (Hedradjat [I14], 2010; Syarif [I2], 2010). This way, Indonesia was able to avoid opening its doors to unwanted external scrutiny of its internal commercial practises (Koh [S2], 2010; Tay [S12], 2010).

Indonesia was also able to further protect their oil palm sector from scrutiny by refusing to ratify the ATHP. Close adherence of the non-interference norm has meant that neither the ASEAN Secretariat, nor any member country could question or pressure any other member state on the issue of ratification.The Indonesian Palm Oil Association (Gabungan Pengusaha Kelapa Sawit Indonesia or GAPKI), a powerful industry lobby group with close links to many ministers and parliamentarians in Indonesia, was instrumental in this decision (Soeharto [I51], 2012). One major concern of GAPKI was the fact that the ATHP allowed for additional protocols, and GAPKI was worried that this may later on include enforcement and liability clauses related to peatlands and use of fire, which would threaten the sector's practices (Interviewee S1, 2010; Interviewee S21, 2010). As a result, Indonesia, the central country implicated in the haze, remains the only member yet to ratify the ATHP (Interviewee A4 \& Interviewee A5, 2010).

\section{Conclusion}

This article has thus argued that effective implementation of environmental agreements depend largely on the style of regional engagement in practice in a particular region. As seen throughout this article, due to the ASEAN style of regional engagement that prioritizes national sovereignty, the negotiations, outcomes, and implementation of ASEAN haze initiatives was strategically shaped by member states to preserve national political and economic interests. Therefore, the outcomes of these initiatives have largely been ineffective in providing long-term, workable solutions for haze. Instead, these initiatives in the spirit of the ASEAN Way have enabled the unscrupulous practises of the regional oil palm sector 
to continue. As a result, instead of offering solutions to the transboundary haze problem, engagement at the ASEAN level has served to protect the interests of the regional oil palm plantation sector, while allowing haze to persist. This approach i.e. the ASEAN Way for haze mitigation is unlikely to change in the near future.

\section{End Notes}

${ }^{1}$ Some interviewees allowed the researcher to use their real names for this research and some preferred to remain anonymous. Therefore, the researcher devised a system to maintain uniformity in the classification of interview sources for this thesis. To indicate the country or institution where the interview was conducted, the letters 'I' for Indonesia, 'M' for Malaysia, 'S' for Singapore, and 'A' for ASEAN is used, along with a number to indicate the order of which the interview was conducted. For example, an interview who allowed himself or herself to be named, who was the tenth to be interviewed in Singapore, would appear referenced as, 'Ali [S10]'. An anonymous interviewee in Malaysia would be referenced as 'Interviewee M5'.

\section{References}

Abdullah [M43], A. M. (2011). Deputy Dean, Faculty of Environmental Studies, Universiti Putra Malaysia. Kuala Lumpur.

Abdullah, A. (2002). A review and analysis of legal and regulatory aspects of forest fires in South East Asia. Jakarta: Project Fire Fight South East Asia.

Aggarwal, V. K., \& Chow, J. T. (2010). The perils of consensus: How ASEAN's metaregime undermines economic and environmental cooperation. Review of International Political Economy, 17(2), 262-290.

Anshari [I42], G. Z. (2011). Center for Wetlands People and Biodiversity, Universitas Tanjungpura. Pontianak.

ASEAN Secretariat. (1995). ASEAN meeting on the management of transboundary pollution.

ASEAN Secretariat. (2002). ASEAN agreement on transboundary haze pollution.

ASEAN Secretariat. (2003). ASEAN peatland management initiative.

ASEAN Secretariat. (2004). 4: Transnational issues. Paper presented at the ASEAN Annual Report. 
ASEAN Secretariat. (2007). Review of existing ASEAN institutional mechanisms to deal with land and forest fires and transboundary haze pollution. Paper presented at the 2nd prepatory meeting for the 2 nd meeting of the Conference of the Parties.

ASEAN Secretariat. (2009). Overview.

Beeson, M. (2007). Regionalism and globalization in East Asia: Politics, security and economic development. New York: Palgrave.

Bernama. (2010, March 30). Palm oil sector to become larger contributor to GDP. Bernama Daily Malaysian News.

Boas, M. (2000). The trade-environment nexus and the potential of regional trade institutions. New Political Economy, 5(3), 415.

Breslin, S., \& Higgott, R. (2003). New regionalism(s) in the global political economy. Conceptual understanding in historical perspective. Asia Europe Journal, 1, 167182.

Campbell, L. B. (2005). The political economy of environmental regionalism in Asia. In T. J. Pempel (Ed.), Remapping East Asia: The construction of a region. Ithaca: Cornell University Press.

Caroko, W., Komarudin, H., Obidzinski, K., \& Gunarso, P. (2011). Policy and institutional frameworks for the development of palm oil-based biodiesel in Indonesia. Jakarta: Center for International Forestry Research.

Casson, A. (2002). The political economy of Indonesia's oil palm sector. In C. J. Colfer \& I. A. P. Resosudarmo (Eds.), Which Way Forward? People, forests and policymaking in Indonesia (pp. 221-245). Singapore: Institute of South East Asian Studies.

Chang, L. L., \& Rajan, R. S. (2001). Regional versus multilateral solutions to transboundary environmental problems: Insights from the Southeast Asian haze. Transboundary Environmental Problems in Asia, 655-670.

Colfer, C. J. P. (2002). Ten propositions to explain Kalimantan's fires. In C. J. Colfer \& I. A. P. Resosudarmo (Eds.), Which Way Forward? People, forests and policymaking in Indonesia (pp. 309-321). Singapore: Institute of Southeast Asian Studies.

Cotton, J. (1999). The "haze" over Southeast Asia: Challenging the ASEAN mode of regional engagement. Pacific Affairs, 72(3), 331-351.

Di, S. (2011). Tread Cautiously. Jakarta: CLSA Asia Pacific Markets. 
Elliott, L. (2000). ASEAN's environmental regime: Pursuing sustainability in Southeast Asia. Global Environmental Change, 10, 237-240.

Elliott, L. (2001). Regional environmental security: Pursuing a non-traditional approach. In A. T. H. Tan \& J. D. K. Boutin (Eds.), Non-Traditional Security Issues in Southeast Asia (pp. 438-459). Singapore: Select Publishing.

Elliott, L. (2003). ASEAN and environmental cooperation: Norms, interests and identity. The Pacific Review, 16(1), 29-52.

Evans, J. W. (2001). Fire, smoke and haze: The ASEAN response strategy (Executive Summary). Philippines: Asian Development Bank.

Fairhurst, T., \& McLaughlin, D. (2009). Sustainable oil palm development in degraded land in Kalimantan. Kent: World Wildlife Fund.

Ferguson, R. J. (2004). ASEAN Concord II: Policy Prospects for participant regional "Development". Contemporary Southeast Asia, 26, 393.

Florano, E. R. (2003). Assesment of the "Strengths" of the new ASEAN agreement on transboundary haze pollution. International Review for Environmental Strategies, $4(1), 127-147$.

Florano, E. R. (2004, March). Regional environmental cooperation without tears or fear: The case of the Asean regional haze action plan. Paper presented at the International Environmental Governance Conference, Paris.

Gomez, E. T. (2009). The rise and fall of capital: Corporate Malaysia in historical perspective. Journal of Contemporary Asia, 39(3), 345-381.

Haryanto [I16], D. (2010). NOAA-MODIS satellites operator, directorate of forest control, Ministry of Forestry, Jakarta.

Hedradjat [I14], N. (2010). Director of crop protection, Ministry of Agriculture, Jakarta.

Ho, W. F. (1997, 2 October). The Big Haze - Indonesian plantations' denial 'incredulous'. The Straits Times.

Hudiono, U. (2003, December 3). RI missing out on ASEAN haze agreement: Activist. Jakarta Post.

Hurrell, A. (1995). Explaining the resurgence of regionalism in world politics. Review of International Studies, 21, 331-358. 
Interviewee A2. (2010). Former ASEAN Secretariat staff. Singapore.

Interviewee A4, \& Interviewee A5. (2010). Environment Division. Jakarta.

Interviewee A7. (2010). Formerly of Environment Division. Jakarta.

Interviewee I25. (2010). Channel News Asia. Jakarta.

Interviewee I49. (2011). Leuser Foundation. Jakarta.

Interviewee S1. (2010). Economy and Environment Program for South East Asia Singapore.

Interviewee S4, \& Interviewee S5. (2010). National Environment Agency. Singapore.

Interviewee S18. (2010). Conservation International. Singapore.

Interviewee S21. (2010). Former Environmental Reporter. Singapore: Straits Times Press.

iStockAnalyst. (2009, November 24). Indonesia's palm oil contributes 4.5 pct to GDP. iStockAnalyst. Retrieved from http://www.istockanalyst.com/

Jarvis, D., Richmond, N., Phua, K. H., Pocock, N., Sovacool, B. K., \& D'agostino, A. (2010). Palm oil in Southeast Asia. Asian Trends Monitoring Bulletin.

Jayasuria, K. (2004). Introduction: The vicissitudes of Asian regional governance. In K. Jayasuria (Ed.), Asian regional governance: Crisis and change. London: Routledge Curzon.

Jones, D. S. (2006). ASEAN and transboundary haze pollution in Southeast Asia. Asia Europa Journal, 4(3).

Kamaruddin [M26], H. (2010). Lecturer, Faculty of Law, UKM. Kuala Lumpur.

Karim, M. S. (2008). Future of the haze agreement: Is the glass half empty or half full? Environmental Policy and Law, 38(6).

Katanyuu, R. (2006). Beyond non-interference in ASEAN: The association's role in Myanmar's national reconciliation and democratization. Asian Survey, 46(6), 5825-5838.

Khalik, A. (2006, October 14). ASEAN ups pressure on haze as lawmakers bicker. Jakarta Post. 
Khoo, N. (2004). Deconstructing the ASEAN security community: A review essay. International Relations of the Asia Pacific, 4(1), 35.

Kim, M. (2011). Theorizing ASEAN Integration. Asian Perspectives, 35, 407-435.

Kivimaki, T. (2001). The long peace of ASEAN. Journal of Peace Studies, 38(1).

Koh [S2], K. L. (2010). Director, Asia Pacific Centre for International Law, NUS. Singapore.

Koh, K. L., \& Robinson, N. A. (2002). Regional environmental governance: Examining the Association of South East Asian Nations (ASEAN) Model. In D. C. Esty \& M. H. Ivanova (Eds.), Global Environmental Governance: Options \& Opportunities. Yale: Yale Center for Environmental Law \& Policy.

Kratochwil, F. V. (1984). The force of prescriptions. International Organization, 38(4).

Kratochwil, F. V. (1989). Rules, norms, and decisions: On the conditions of practical and legal reasoning in International Relations and Domestic Affairs Cambridge: Cambrdige University Press.

Kurniawan, M. N. (2002, November 15). RI to speed up ratification of ASEAN haze accord. Jakarta Post.

Letchumanan [A6], R. (2010). Head, ASEAN Environment Division. Jakarta.

Lew [M6], S., \& Interviewee M7. (2010). Peatland Programme, Global Environment Center. Kuala Lumpur.

Lim [S13], M. A. (2010). Manager, policy research, Singapore Institute of International Affairs. Singapore.

Mat Akhir [A1], A. (2010). Former Senior assistant to ASEAN secretary general. Kuala Lumpur.

Mayer, J. (2006). Transboundary perspectives on managing Indonesia's fires. The Journal of Environment \& Development, 15(2), 202-233.

Mccarthy, J. F. (2010). Process of inclusion and adverse incorporation: Oil palm and agrarian change in Sumatra, Indonesia. The Journal of Peasant Studies, 37(4), 821-850.

Murray, P. (2010, 27-29 September). The European Union as an integration entreprenur in East Asia - Yardstick or cautionary tale? Paper presented at the Australian Political Studies Association Conference, Melbourne. 
Nagulendran [M34], K., \& Interviewee M35. (2010). Deputy Under Secretary, Ministry of Natural Resources and Environment and officer, Putrajaya.

Narine, S. (1998a). ASEAN and the management of regional security. Pacific Affairs, 71(2), 195.

Narine, S. (1998b). Institutional theory and Southeast Asia: The case of ASEAN. World Affairs, 161, 33.

Nesadurai, H. (2003). Attempting developmental regionalism through AFTA: The domestic sources of regional governance. Third World Quarterly, 24, 235.

Nesadurai, H. (2008). The Association of Southeast Asian Nations (ASEAN). New Political Economy, 13(2), 225.

New Straits Times. (1997, September 25). EPSM wants haze constituents to be made public.

Nguitragool, P. (2011). Negotiating the haze treaty. Asian Survey, 51(2), 356-378.

Parliament of Singapore. (1998). ASEAN region haze action plan (fulfillment of obligations) (1998-01-15).

Pempel, T. J. (2005). Introduction: Emerging webs of regional connectedness. In T. J. Pempel (Ed.), Remapping East Asia: The construction of a region. Ithaca: Cornell University Press.

Pichler, M. (2011). Palm oil and agrofuels in Southeast Asia: A political ecology framework for studying human-nature interactions and the role of the state. Paper presented at the International Conference on International Relations and Development, Thailand.

Resosudarmo [I26], B. P. (2010). Associate Professor, Development and Environmental Economics, Jakarta.

Reuters. (2011, February 7). Update 1 - Wilmar to invest $\$ 900 \mathrm{mln}$ in Indonesia palm oil product plants.

Roswiniarti [I13], O. (2010). Director, Remote Sensing Data Centre, Indonesian National Institute of Aeronautics and Space. Jakarta.

Sawit Watch. (2008). Satu dekade bersama sawit watch. Bogor: Sawit Watch.

Severino, R. C. (1999). Fighting the haze: A regional and global responsibility. Paper 
presented at the Final Regional Workshop of the Regional Technical Assistance Project on Strengthening ASEAN's Capacity to Prevent and Mitigate Transboundary Atmospheric Pollution.

Severino, R. C. (2006). Southeast Asia in Search of an ASEAN community: Insights from the former ASEAN Secretary-General. Singapore: ISEAS.

Severino, R. C., Hew, D., Suryadinata, L., Hsu, L., \& Moeller, J. O. (2005). Framing the ASEAN charter. Singapore: ISEAS.

Shelton, D. (2003). Commitment and compliance: The role of non-binding norms in the international legal system. New York: Oxford University Press.

Smith, A. L. (2004). ASEAN's ninth summit: Solidifying regional cohesion, advancing external linkages. Contemporary Southeast Asia, 26, 416.

Soeharto [I51], R. (2012). Executive Chairperson, Indonesian Sustainable Palm Oil Commission. Jakarta.

Solingen, E. (1999). ASEAN, Quo Vadis? Domestic coalitions and regional co-operation. Contemporary Southeast Asia, 21(1), 30.

Solingen, E. (2005). East Asian regional institutions: Characteristics, sources, distinctiveness. In T. J. Pempel (Ed.), Remapping East Asia: The construction of a region. Ithaca: Cornell University Press.

Syarif [I2], L. M. (2010). Chief cluster of security and justice governance, Kemitraan Partnership, Jakarta.

Tan [S7], A. K. J. (2010). Vice Dean, Faculty of Law, NUS. Singapore.

Tan,B. (2005). The norms that weren't: ASEAN's shortcomings in dealing with transboundary air pollution. International Environmental Politics, Spring 2005.

Tan, K. T., Lee, K. T., Mohamed, A. R., \& Bhatia, S. (2009). Palm oil: Addressing issues and towards sustainable development. Renewable and Sustainable Energy Reviews, $13,420-427$.

Tay [S12], S. S. C. (2010). Chairman, Singapore Institute of International Affairs. Singapore.

Tay, S. (1998). South East Asian forest fires: Haze over ASEAN and international environmental law. Reciel, 7(2), 202-208. 
Tay, S. (2008). Blowing smoke: Regional cooperation, Indonesian Democracy, and the haze. In D. K. Emmerson (Ed.), Hard choices. Singapore: ISEAS.

Tay, S. S. C. (2002). Fires and haze in Southeast Asia. In P. J. Noda (Ed.), Cross-sectoral partnerships in enhancing human security (pp. 53-80). Tokyo: Japan Center for International Exchange.

Van Gelder, J. W. (2004). Greasy palms: European buyers of Indonesian palm oil. Castricum: Friends of the Earth.

WALHI, Sawit Watch, \& CELCOR. (2009). Malaysian Palm Oil and logging investments and operations.

World Growth. (2011). The economic benefit of palm oil to Indonesia. Virginia: World Growth.

Yahaya [M13], N. (2010). Former Deputy Secretary General, Ministry of Natural Resources and Environment. Kuala Lumpur.

Yahaya, N. (2000). Transboundary air pollution: Haze pollution in Southeast Asia and its significance. Journal of Diplomacy and Foreign Relations, 2(2), 41-50.

Zainal Abidin [M38], A. (2010). Deputy Director, Pusat Tenaga Malaysia. Kuala Lumpur. 
